\title{
CZY CHRZEŚCIJANIN MA PRAWO ŻYWIĆ NADZIEJĘ DOTYCZĄCĄ TEGO ŚWIATA? \\ Rozważania o pojęciu laski jako nadziei w obliczu zagrożenia naszej egzystencji na ziemi
}

\section{Uwagi wstepne}

1. Nie ma wątpliwości, że łaska stanowi dzisiaj pojęcie problematyczne. Każdy znający choćby pobieżnie dziejowe koleje teologii łaski wie, jak wielokształtne i różnorodne zastosowanie znajdowało słowo „łaska”. Może to stanowić wskazówkę tego, że pojęcie to jest podatne na przekształcenia i wciąż może i musi być przypasowywane do nowych potrzeb. Nasuwa to także myśl o możliwym nieporozumieniu a nawet nadużyciu.

Także dzisiaj łaska bywa bardzo często używanym, lecz równocześnie łatwo wypaczanym słowem w mowie pobożnej. Obrotność językowa niektórych mówców religijnych nie zna granic w używaniu tego słowa. Dla wielu jednak słowo to nie posiada prawie żadnej heurystycznej wartości. Co znaczą dla nich takie zdania: Bóg daje łaskę lub jej odmawia? Człowiek jest w stanie łaski? Łaska jest „wlana”? Czyż laska nie jest tutaj rozumiana jako substancja niewidzialna, jakiś fluid energetyczny, podatny na powiększenie lub zanik? Co znaczy owa „niewidzialna substancja”? Czy przysługuje jej w codziennym życiu jakieś znaczenie?

Słowo „łaska” zatraciło w dużej mierze swoją pozycję, jaką cieszyło się w przeszłości. Królowie i inni władcy, idąc za wzorem Karola Wielkiego, przypisywali sobie, słusznie lub niesłusznie, formułę „Dei gratia” — „władcy z łaski Bożej”. Coraz rzadziej trafiają się „łaskawi panowie i panie”, którzy rzeczywiście odnoszą się do bliźnich z łaskawością, podobnie jak Bóg, i łaskę wysuwają przed prawo lub zasługę. Za ujmę uważa się dzisiaj „jeść łaskawy chleb” lub tylko otrzymać coś „z łaski”. Człowiek wzbrania się nawet przed przyjęciem czegoś „gratis”. To i wiele innych czynników sprawia, że słowo „łaska” zostało zdegradowane do mniej lub bardziej pustej atrapy leksykograficznej.

* Tekst wykładu wygłoszonego po niemiecku w Papieskiej Akademii Teologicznej w Krakowie 5 V $1989 \mathrm{r}$. 
Tam jednak, gdzie „łaska” nie stanowi istotnego elementu w życiu społecznym i gdzie nawet samo słowo „łaska” podlega dyskredytacji, czy człowiek nie staje się „ogołocony z łaski” (gnadenlos)? Czyż musi on żyć bez rzeczywistości, która się zowie łaską? Chrześcijańska teologia łaski będzie musiała dowieść, że człowiek dzisiejszy potrzebuje rzeczywistości, określonej mianem „łaska”, nie mniej niż potrzebował tego człowiek dawniej. Teologia ta winna zainteresować się zmienionym zasięgiem doświadczenia i wykazać, że człowiek obok prawa, sukcesu, zasługi, przypadku i konieczności doświadcza także wolnej, osobowej pomocy i miłości i że tego potrzebuje. Ponieważ „rzeczywistość łaski”, może być łatwiej i bardziej wyraziście przedstawiona w oparciu o analogię z tymi międzyludzkimi relacjami, wobec tego niektórzy teologowie zaproponowali, żeby słowem „łaska” posługiwać się oszczędnie ${ }^{1}$, ale samą rzecz tym dobitniej uwydatnić. Podobny sposób będzie zastosowany tutaj, gdzie chodzić będzie o odpowiedzialne przekazywanie człowiekowi dzisiejszemu bogactwa Ewangelii łaski.

2. O łasce winno się mówić na tle dzisiejszych doświadczeń. Jest to metodologiczny pewnik. Przed teologią laski, podobnie jak przed teologią systematyczną w ogóle, stoi zadanie skonfrontowania tradycyjnego przekazu wiary z mentalnością i problemami teraźniejszości i nadania mu przez to nowej przystępności i trafności.

Teologia dogmatyczna jest kompetentna w określaniu związku przekazywanej wiarý z chwilę obecną. Nie musi ona, przy zachowaniu szacunku dla tradycyjnych wypowiedzi doktrynalnych, uzupełniać badawczych ustaleń nauk humanistycznych. Od nich, a w szczególności od filozoficznej antropologii, uczy się rozpoznawać zakres wypowiedzi i ich rozumienia, w którym dochodzi do głosu i artykułuje się ludzkie oczekiwanie na zbawienie. Przyuczenie to uzdatnia teologię do takiego formułowania wypowiedzi teologicznych i ich przekazywania, aby uchwytne w nich było ich znaczenie antropologiczne. Oczywiście dogmatyka nie ma prawa zatracić się w antropologii filozoficznej. Jej naukowa refleksja wychodzi świadomie z przekazanego orędzia wiary. Może ona iednak daleko iść za naukowymi analizami humanistyki i akceptować antropologiczne wyniki jej badań. Również ona może naświetlić główny problem świadomości człowieka, wskazując na jego zorientowanie ku swemu ,ja”, z równoczesnym otwarciem się na świat, przez wyeksponowanie daru mowy i wolności. Teoiogia dogmatyczna nie ma prawa w żadnym wypadku - jak to czynią inne nauki - ominąć doświadczenia cierpienia i śmierci.

W dotychczasowych rozważaniach był wprowadzany wyraz „doświadczenie” jako zrozumiały sam przez się. Pojęcie „doświadczenie”, jakkolwiek od XVIII wieku stało się oklepanym komunałem, należy do najmniej wyjaśnios.13.

${ }^{1}$ Por. G. Greshake, Geschenkte Freiheit in die Gnadenlehre, Freiburg-Basel-Wien 1977, 
nych pojęć dzisiejszej myśli. Nie ma możliwości wyjaśnić go także tutaj. Aby jednak jakoś było rozumiane w dalszych wywodach, trzeba o nim powiedzieć to, co jest najkonieczniejsze.

Pojęcie doświadczenia nie zawiera w sobie zwykłego przeżycia, lecz nastawia się raczej na rodzaj i sposób, w jaki człowiek, jako człowiek, wchodzi w kontakt ze światem i w jaki uobecnia świat w sobie, a siebie w świecie. Doświadczenie jest sposobem, w jaki tłumaczymy całą napotkaną rzeczywistość w każdorazowym konkretnym kontekście.

Semantyka tak łacińskiego słowa experientia, jak i niemieckiego słowa Erfahrung, dostarcza wartościowych elementów do wyjaśnienia treści tego pojęcia. Łacińska experientia zbudowana jest z przyimka ex i z czasownika perior. Periri znaczy: trudzić się. Periri wykazuje nadto pokrewieństwo ze słowem peri-culum (niebezpieczeństwo). Tak więc peritus to człowiek doświadczony w niebezpieczeństwie, a więc dzięki temu mądry (biegły). Ex-pert posiada znajomość rzeczy, ponieważ przeszedł zwycięsko przez niebezpieczeństwa. Taki sam związek między wiedzą a niebezpieczeństwem występuje w niemieckim Erfahrung. Człowiek doświadczony (Erfahrener) to ten, który przeszedł przez niebezpieczeństwa (Gefahr) i wszystkie przezwyciężył. Semantyka słowa pozwala w obydwu przypadkach — jak jest w języku polskim nie wiem — rozpoznać, że doświadczenie zespala ze sobą znajomość rzeczy z niebezpieczeństwem. Na poziomie egzystencjalnym ma to następujący sens: człowiek wychodzi z siebie, spotyka innych ludzi i pozostałą rzeczywistość, zbliża się do nich, wystawia się na niebezpieczeństwa i przechodzi próby, aby ubogacony przez nie, mógł z powrotem być sobą. Tylko takie doświadczenie czyni go osobą (buduje jego ,ja”).

Czy jednak łaska jest doświadczalna? Było powiedziane, że łaska nie stanowi dzisiaj „słowa - klucza”, a „doświadczenie” jest takim słowem ${ }^{2}$. Z tego powodu teologia łaski będzie się musiała nolens volens ustosunkować do współczesnego wymogu otwartości na możliwe doświadczenie i łaskę z konieczności ustawić w kontekście doświadczenia ludzkiego życia na ziemi.

3. Jestem świadomy tego, że staram się na tym miejscu zaprezentować tylko jeden aspekt łaski, w przeszłości raczej pomijany. Chodzi mi w pierwszym rzędzie o to, co źródła nauki o łasce mają do powiedzenia w stosunku do naszej niebezpiecznej sytuacji doczesnej: Czy łaska pozwala nam w tym miejscu mieć nadzieję? Nie chodzi w tym przypadku o rozwijanie teologii łaski. Jednakże skoro łaska stanowi samą esencję uchwytnej w dziejach łaskawości i miłości Trójjedynego Boga, wówczas powinna się w niej zawierać także nadzieja na szczęście w tym świecie, a szczególnie taka nadzieja, która kształtuje zasadniczą postawę człowieka na przyszłość.

${ }^{2}$ Por. W. Bernet, Gebet, Stuttgart-Berlin 1970, s. 57. 
Życie ludzkie zawiera trzy wymiary: teraźniejszość, przeszłość i przyszłość. Tytuł obecnej rozprawy nie przeocza przeszłości, lecz zwraca uwagę głównie na teraźniejszość i przyszłość. Nawiązuje ona nadto do dwóch wymiarów przyszłości, a mianowicie doczesno-ziemskiej i nadprzyrodzono-wiekuistej. Tak więc jawią się trzy części rozprawy:

I. To życie jest życiem wiecznym

II. Doczesna (innerweltlich) przyszłość tego życia

III. Eschatologiczna „wartość dodana” (Mehrwert) tego życia

\section{Ponowne odkrycie:}

\section{TO ŻYCIE JEST ŻYCIEM WIECZNYM}

Było tragiczną pomyłką sprowadzać „życie wieczne” do tego, co się zaczyna dopiero przy końcu tego życia. Przez to życie ziemskie bywało sprowadzane do roli „przedsionka” wieczności. Jego jedyna wartość polegała na tym, że było ono pewnym egzaminem wstępnym do życia wiecznego. Tymczasem jest bezspornym faktem, że dzisiejszy bezstronny człowiek nie widzi w tym życiu niczego innego niż właśnie to życie. Dzisiejsza egzegeza dowodzi dalej, że według ujęcia biblijnego, życie jest nierozłącznie zespolone z życiem wiecznym. Pismo, teologia Ojców i wielka Tradycja dogmatyczna uważają obydwa stany życia za identyczne w tym sensie, że to życie i wszystko w nim dokonane znajdą w eschatonie swoje dopełnienie i udoskonalenie. W Sumie teologicznej św. Tomasza jest powiedziane ( $\left.\mathrm{I}^{\mathrm{a}} \mathrm{I} \mathrm{I}^{\text {ae }} 114,3 \mathrm{ad} 3\right)$ : „Gratia est vita aeterna in virtute” (łaska jest życiem wiecznym w mocy). Łaska jest zarodkiem, zaczątkiem, wzorcem życia odkupionego. Życie wieczne jest więc tym, czym teraz już jest zadatek w łasce. Życie wieczne zaczyna się już tutaj.

Wypowiedź, że to życie jest życiem wiecznym, jest w swej podwójnej oporności dopiero wtedy dobrze uchwycona, kiedy się pamięta o rozdźwięku między tym a tamtym światem, który pojawił się w zachodniej teologii w następstwie nauki „Doktora łaski”. Augustyn doświadczył, jak prawie nikt inny, niewoli zła w sobie samym. Po swojej „konwersji” uświadomił sobie, jak rozdartym, wewnętrznie zniewolonym i niepełnym człowiekiem był dawniej. Doświadczał on łaski jako owej mocy, która go odmieniła w samym jego wnętrzu.

Jeśli w teologii przedaugustyńskiej łaska była stosowana do całego - wewnętrznego i zewnętrznego - dzieła zbawienia, - u późnego Augustyna była ona rozumiana w pierwszym rzędzie jako niewidzialno-wewnętrzna moc Ducha Świętego, uzdrawiająca i uświęcająca człowieka, która w jakimś sensie nadaje ludzkiemu sercu odpowiednią „moc ciążenia”, i pobudza człowieka do

${ }^{3}$ Por. G. Gresh a ke, Gottes Heil-Glück des Menschen. Theologische Perspektiven, Freiburg 1983, s. 19. 
pożądania „szczęścia nadziemskiego”. Do podstawowych twierdzeń Augustyna należy i to, że człowiek i jego ziemski świat został zniszczony przez grzech, a Bóg nielicznych wybranych wiedzie dzięki temu ku zbawieniu, że ich „wewnętrznie" obdarza łaską i daje im niewidzialny udział w zbawieniu zbliżającego się królestwa Bożego. Zbawienie sprawiane bywa przez samego Boga, bez żadnego ludzkiego udziału ${ }^{4}$.

Człowiekowi, zainteresowanemu wyłącznie łaską indywidualną i wewnętrzną, właściwie nie zależy na realizacji szczęścia i zbawienia w doświadczanym świecie ziemskim. Swiat ten jest dla niego albo bez wartości, albo grzechem, albo ostatecznie bez znaczenia dla zbawienia. Całe jego usiłowanie dotyczy szczęścia tamtego świata. Dobra tego świata są z powodu ich znikomości i skończoności w najlepszym razie jasnym dowodem na to, że tutaj nie może być prawdziwej radości, rzeczywistego pokoju i autentycznej miłości. Życie na tym świecie nie ma czego oczekiwać.

Po Augustyńsku uwewnętrzniona, uduchowiona i zindywidualizowana łaska posiada w świecie zachodnim swoją historię oddziaływania, którą F. Heer tak charakteryzuje: „W rozłączeniu szczęścia ziemskiego od niewidzialnego znajdzie się źródło współczesnej niewiary w szczęście: w negatywnym określeniu szczęścia jako niepewnego „szczęścia ułudy” w tym lichym świecie, znajduje się zarodek tego skurczenia i przewartościowania szczęścia, który sprawia, że staje się ono rzeczą tanią, którą można zrobić lub kupić [...]. Kiedy widzialny i niewidzialny świat rozpadają się na dwoje, wówczas zbawienie przesuwa się w nieokreśloną dal, gdzie przyciemnia się i blednie, stając się mgławicowym zlepkiem wartości i ideologii, podczas gdy szczęście [tego świata!] staje się bezwartościową monetą codzienną" . Spirytualistyczna redukcja łaski zuboża biblijne jej ujęcie, jako że w Piśmie laska zawiera się w pozytywnym, osobowym i dziejowym stosunku trójjedynego Boga do człowieka: stanowi samo centrum miłości i życzliwej dobroci Boga. Ale to musiało być znowu dopiero odkryte.

Lata czterdzieste i pięćdziesiąte naszego wieku przyniosły znaczną odnowę w nauce o łasce. Pomimo wrogości ze strony neoscholastyki, która w roku 1950 otrzymała mocne wsparcie w encyklice Humani generis, niektórzy teologowie, jak np. J. B. Alfaro, H. U. von Balthasar, M. Flick, H. de Lübac, Y. Congar, K. Rahner, H. Rondet i inni, zdołali nieco szerzej opisać pojęcie łaski. Wykazali oni, że Pismo określa mianem łaski także to, kiedy Bóg człowiekowi udziela samego siebie, zamieszkuje w nim i włącza go we własne życie. Bóg nie daje „czegoś, lecz daje „wszystko”, mianowicie siebie samego. Udział w życiu Boga jest tym, do czego czlowiek faktycznie od samego stworzenia jest prze-

${ }^{4}$ Por. G. G res h a ke, Glück und Heil, [w:] Christlicher Glaube in moderner Gesellschaft, Bd. 9, Freiburg 1981, s. 114.

${ }^{5}$ F. He er, Glück und Glückseligkeit, [w:] tegoż, Gesammelte Vortrage, Bd. 2, Nürnberg 1956, s. $13-32$ (zwł. s. 19 n.). 
znaczony. Udział ten nie jest człowiekowi, zamkniętemu w sobie (natura pura), dopiero potem ,zaszczepiony” (übergestülpt). Nie istnieją dwa wzajemnie od siebie oddzielone poziomy, mianowicie poziom naturalny i nadprzyrodzony, i to w taki sposób, żeby nadprzyrodzona łaska musiała się wdzierać siłą do naturalnego człowieka. Raczej: gratia non destruit sed supponit naturam et perficit eam. Żyjący w dziejach człowiek, jako stworzenie duchowe, jest „imago Dei” a więc i „capax Dei”, jest otwarty na łaskę i zdolny do przyjęcia wolnego samoudzielenia się Boga. Duch człowieka jest otwarty na nieograniczony zakres bytu i może być podniesiony do bezpośredniego oglądania Boga, chociaż mu się to z prawa nie należy. Zwolennicy tej „,nowej teologii” widzieli w człowieku stworzenie, noszące w sobie naturalne pragnienie oglądania Boga (desiderium naturale). Rozum ludzki nastawiony jest na nieograniczone poznanie rzeczywistości, a w ogóle na równie nieograniczone posiadanie dobra. Ich naturalne pragnienie osiąga swój ostateczny cel w bezpośrednim zjednoczeniu ze źródłem bytu i dobra. Tylko oglądanie Boga może zaspokoić naturaIne pragnienie duchowego stworzenia. Łaska jest nie tylko najwyższą doskonałością natury, lecz także jedynym i ostatecznym jej udoskonaleniem: natura jest zdolna nie tylko przyjąć łaskę; co więcej - bez łaski nie potrafi znaleźć swojego spełnienia ${ }^{6}$. W momencie, w którym Bóg stwarza człowieka, w jego naturze umieszcza przesłanki do przyjęcia łaski przez to, że wyposaża go w „naturalne pragnienie oglądania Boga”. W tym ujęciu laska jest odpowiedzią na nieugaszoną tęsknotę człowieka za szczęściem, na głód i pragnienie miłości i bezpieczeństwa - jednym słowem, jest ona spełnieniem się jego nadziei. Łaska nadprzyrodzona nie jest więc - i to jest decydujące - czymś, co bywa przydawane ludzkiemu „naturalnemu” pragnieniu dopiero u kresu jego życia. Do tego momentu musiałby on, usychając, trwać bez laski. Łaska jest już teraz aktywna; w tym życiu staje się ona zarodkiem tego, co kiedyś ma w pełni rozkwitnąć. Gdy człowiek wierzący ustawia drogę własnego życia na Boga, już w tym jest uobecniony cel, jako wielkość zaczątkowa i zdolna się rozwijać w wierze, nadziei i miłości.

$\mathrm{Z}$ tego punktu widzenia łaska nie jest już tylko wewnętrznym i indywidualnym wytyczeniem kierunku, lecz także dotyczy i ogarnia całe „,naturalne życie człowieka i skierowuje je wraz z jego światem ku zbawieniu nadnaturalnemu. Całe ludzkie życie jest przez nią naznaczone; dlatego też nie może już istnieć żaden rozdział między tym i tamtym światem, między dziedziną „tylko-światową" i wieczną. Dla człowieka, znajdującego się w stanie łaski, wszystkie tzw. „światowe” doświadczenia i sprawy stają się środkami, w których on dorasta do swojego ostatecznego celu. Ten cel jest już doświadczalnie obecny na sposób zadatku. Życie ziemskie jest prawdziwą częścią życia wiecznego.

${ }^{6}$ J. B. Alfaro, Natur und Gnade, [w:] Lexikon für Theologie und Kirche, Bd. 7, Freiburg 1962 , s. 833 . 
Łaska działa w takim np. człowieku, który usiłuje opanować własny egoizm i dlatego gotów jest raczej znieść krzywdę niż dążyć do postawienia na swoim. Łaska jest tam, gdzie człowiek spotyka drugiego i interesuje się jego sytuacją, pomaga mu, z nim się cieszy i go miłuje. Łaska uzdalnia człowieka do tego, żeby słuchał bez oglądania się na własny zysk. Z łaską mamy do czynienia wtedy, gdy jeden nie zmusza drugiego do akceptacji własnych poglądów, gdy człowiek nie stosuje gwałtu do nikogo. Łaska tworzy nowego człowieka, przeżywającego także nowe życie ziemskie.

Autorzy „nowej teologii” otwarli, co prawda, pojęcie łaski na doświadczaIną rzeczywistość tego świata; pozostawali jednak nadal związani kontekstem i terminologią neoscholastyczną i dlatego szersze uświadomienie problemu dokonało się dopiero w latach sześćdziesiątych i siedemdziesiątych. Wówczas dopiero przesunęły się $w$ centrum teologicznej dyskusji zagadnienia związane z teologią stworzenia, z rzeczywistością społeczno-polityczną, eklezjalną i wreszcie eschatologiczną. Podjęta została w teologii łaski — w sposób dawniej niespotykany — odpowiedzialność człowieka i ludzkości za siebie i za świat. Działanie zmieniające świat zostało uznane za przejaw obecności łaski. A ponieważ odpowiedzialność za świat dotyczy nie tylko teraźniejszości, lecz również przyszłości, musiała teologia zaprezentować przyszłościowy wymiar łaski.

\section{Rozwinięcie:}

\section{DOCZESNA PRZYSZŁOŚC TEGO ŻYCIA}

Teologia posunęła się do wypracowania tego wymiaru łaski, który dawniej był prawie nie dostrzegany. Łaska jako siła napędowa w działaniu przemieniającym świat; łaska jako historyczna i historyczno-zbawcza moc. Pytanie nie może już teraz brzmieć — tak jak u Lutra: „Jak ja sobie poradzę z łaskawym Bogiem?” (na sądzie eschatologicznym), ale winno brzmieć: „Jak osiągniemy lepsze społeczeństwo?" Jakie należy podjąć zmiany struktur, aby w przyszłości było zapewnione szczęście możliwie wielu ludzi? „Znaki czasu” sprzyjały odrodzeniu mentalności utopijno-eschatologicznej. Pytano się o znaczenie chrześcijaństwa dla odnowienia świata. W roku 1970 pisał H. Mühlen: „Każdy, kto w przyszłości będzie mówił o łasce, będzie musiał zaraz na początku powiedzieć o koniecznych zmianach struktur społecznych, aby w ten sposób stworzyć wokół przestrzeń dla spotkania człowieka z Bogiem. Kto w strukturach dotychczasowych swojego bytowania [...] nie mógł żyć w sposób godny człowieka, dla niego jest niewiarygodny przekaz o łasce Bożej jako sprawiedliwości, miłości i pojednaniu. W tym znaczeniu tradycyjna nauka o łasce musi zostać uświatowiona, tzn. musi się stać widoczna jako rewolucyjna siła miłości, która 
dla chrześcijan staje się motywem do współpracy nad budowaniem i urządzaniem ludzkich struktur społecznych"?.

W latach siedemdziesiątych doszło się do nowych koncepcji łaski, które wnikały bardziej w oryginalność dzisiejszego doświadczenia. Trzeba tutaj wspomnieć o trzech tego rodzaju szkicach: $\mathrm{H}$. Küng rozumie łaskę jako wyposażenie do tego, żeby mogło zaistnieć prawdziwe człowieczeństwo, które staje się udziałem każdego, kto włącza się w Jezusa Chrystusa i Jego prawdziwie radykalny humanizm; E. Schillebeeckx, O. H. Pesch, L. Boff i G. Greshake pojmują łaskę jako moc wyzwalającą lub wolność ofiarowaną, a L. Weimer widzi w niej raczej uzdolnienie do „radowania się w Bogu i w Jego dziele”. Te i inne projekty, które wyraźnie wchodzą w specyficzny świat doświadczeń człowieka współczesnego, wypracowały takie rozumienie łaski, które widzi w niej wyłącznie pomoc zdolną przezwyciężyć zagrażające ludzkości pesymistyczne i rozpaczliwe lęki. Projekty te przygotowują drogę nadziei na życie także w tym świecie.

W dalszych wywodach łaska będzie świadomie postawiona w kontekście całkowicie konkretnych rzeczywistości ziemskich. Pojawi się wyraźne pytanie: czy chrześcijanin ma prawo żywić doczesną nadzieję? Powszechnym znamieniem naszego świata jest zagubienie pewności co do przyszłych losów. Wielu ludzi zwątpiło w przyszłe szanse tego życia. Widzą oni swoją egzystencję ze wszystkich stron zagrożoną. Stoją bezradni przed najbardziej pilnymi zadaniami humanistycznego ukształtowania świata: bezrobocie, ubóstwo, niesprawiedliwość społeczna, eksplozja demograficzna, wyścig zbrojeń itp. wymknęły się spod kontroli. Lasy umierają dzisiaj w Europie w następstwie kwaśnego deszczu, a w tropiku pod uderzeniem człowieka. Rzeki i morza są zabrudzone odpadkami i chemią. Wymieranie fok, kwitnienie alg, dziura ozonowa stały się hasłami dnia. Gospodarka rabunkowa wciąż przybiera na sile. W każdej godzinie umiera na ziemi jeden gatunek roślin, a każdego dnia jeden gatunek zwierząt. Zniknęła iluzja, że sami możemy wziąć przyszłość w swoje ręce i ją zorganizować. Na grzbiecie coraz nowych środków zabezpieczających wyrastają coraz większe niepewności: ryzyko w zakładach z reaktorami atomowymi, oparzenia przy naświetlaniach leczniczych itd. „Postęp” zdaje się pożerać własne osiągnięcia, jak Moloch. Ufne oczekiwanie godnej człowieka przyszłości zostało dogłębnie zachwiane. Fala lęku przetacza się przez ludzkość.

Sytuacja ludzkości przedstawia się kiepsko. Lecz można się zapytać: czy nie jawi się żaden ratunek? Czy teraźniejszość nie wysyła „sygnałów” takiej nadziei, które już same są laską. Niekiedy wydaje się, że ten, kto dzisiaj mówi o nadziei, upodabnia się do zaklinacza używającego czarodziejskich formułek, które już dawno utraciły swoją moc przekonywania. Mimo to, czy można za-

${ }^{7}$ H. Mühlen, Gnadenlehre, [w:] Bilanz der Theologie im 20. Jahrhundert, hrsg. von H. Vorgrimler, P. van der Gucht, Bd. 3, Freiburg 1970, s. 188 n. 
mykać oczy przed sygnałami nadziei? A takie istnieją. Trzeba wymienić cztery wpadające w oczy znaki nadziei.

\subsection{Rodzi się nowa świadomość świata}

Z perspektywy ekologicznej dotychczasowe dzieje ludzkości da się podzielić na trzy epoki. Pierwsza pokazuje nam człowieka zanurzonego w naturze. Żył on w jaskiniach i zabiegał o kontakt z zastanym światem. Oczywiście był on również wystawiony całkowicie na jego niebezpieczeństwa.

Druga epoka zaczęła się, gdy człowiek zabrał się do przekształcania świata. Poszerzał sobie przestrzeń, którą naznaczał własnym działaniem. Ciągnął kanały nawadniające, uprawiał pola i budował sobie domy. W ten sposób wyciskał na świecie swoje piętno. Ale i teraz poza jego dokonaniami łatwo przychodziło rozpoznać pierwotny świat. Wtórny świat człowieka był w sposób widoczny wbudowany w świat zastany i wykonany z jego materiału.

Dopiero w trzeciej, naukowo-technicznej epoce człowiek zabiera się do zmiany oblicza ziemi, tak że świat pierwotny jest prawie nie do poznania. $\mathrm{Z}$ tym zmienia się gruntownie stosunek człowieka do świata. Tworzy on sobie taki świat, jaki w swojej rozwijającej się naukowo-technicznej doskonałości jest ukierunkowany na jego potrzeby. Kontakt ze światem pierwotnym w najlepszym razie pozostał jako coś pośredniego. Okazuje się to w zwyczajnych rozmowach dzieci z wielkiego miasta, dla których koń wypadł z pola widzenia, a czymś pierwotnym stało się auto. Dla nich koń jest jakimś „,pseudomotorem na owies". Ujawnia się tutaj całkowicie odmienny stosunek do świata niż był u podstaw takich określeń, jak „Tretesel” [osioł drepczący] lub „Dampfross” [rumak parowy]. Przez naukę i technikę człowiek czasów nowożytnych postanowił zdobyć bezwzględne władztwo nad światem. Uczynił z siebie miarę wszystkich rzeczy.

Dzisiaj staje się dla nas jasne, że jeśli człowiek będzie trwał w ramach tej perspektywy, to z czasem zniszczy totalnie świat pierwotny. Dlatego wielu ludzi nie chce tak dalej żyć, jak gdyby nie istniał świat pierwotny. Nie chcą tego, żeby pewnego dnia trzeba było stwierdzić z bólem że rzeczywiście już go nie ma. Byłby to bowiem upadek także świata zbudowanego przez nas samych. Budzi się u coraz większej liczby ludzi tęsknota za światem pierwotnym. Ale gdzie go można znaleźć? W okręgach chronionych [przez prawo], w parkach narodowych, rezerwatach lub w krajach nierozwiniętych? Oczywiście, ale nie wyłącznie. Może on być rozpoznany jako odsunięta i zaprzeczona prawda świata wtórnego. Ten wtórny świat nie musi być zanegowany, lecz przejrzany dogłębnie i sprowadzony do jego właściwej podstawowej prawdy. Dzisiejsza wiedza przyrodnicza wie, że nie chodzi o wykluczenie naukowo-technicznego rozumu, ale o jego instrumentalne zastosowanie tam, gdzie wymaga się roz- 
wiązania typu instrumentalnego. Ma się rozumieć, że nie można od niego oczekiwać więcej, niż może on uczynić. Rozum jest sam świadomy swoich granic. On sam pokazal, że winniśmy porzucić niejedno z tego, czego nam dostarcza świat wtórny. Nie mamy prawa postępować dalej według wyłącznie naszego widzimisię. Świat pierwotny ma bowiem pewne zasady, które wymykają się naszym rządom i tylko z wielką szkodą mogą być łamane. Największą pomyłką człowieka było przekonanie o jego absolutnej przewadze nad przyrodą. Ziemia nie potrzebuje człowieka w taki sam sposób, jak człowiek ziemi. Ten pogląd, dzisiaj wcale nie odosobniony, może być uważany za dzieło łaski, która zapowiada otwarcie na życie doczesne.

\subsection{Nowe rozumienie nauki opanowuje świat myśli}

Nowoczesne nauki przyrodnicze oparły się na ściśle określonym pojmowaniu rzeczywistości, które (pojmowanie) tak charakteryzuje sławna parabola angielskiego astrofizyka A. Eddingtona, zamieszczona w książce z 1939 roku The Philosophy of Phisical Science. Przyrodnik zachowuje się jak ichtiolog, który zarzuca sieć do morza, wyciąga połów na ląd i poddaje go naukowej ocenie. W oparciu o pewne cechy ryb stawia dwa podstawowe prawa ichtiologii: (1) Wszystkie ryby mają więcej niż $5 \mathrm{~cm}$ długości (2) Wszystkie ryby posiadają skrzela. Zastrzeżenie: wiadomo, że istnieje niezliczona ilość ryb mniejszych niż $5 \mathrm{~cm}$, które jednak przy wielkości oczek tej sieci nie mogą być złapane. Reakcja ichtiologia: czego nie mogę chwycić moją siecią, leży zasadniczo poza wiedzą o rybach. Nie zajmuje się ona żadnym obiektem tego gatunku, który nie został w ichtiologii zdefiniowany jako jej obiekt... Czego nie mogę złowić, nie jest rybą. Ta parabola jest charakterystyczna dla nowożytnej wiedzy w ogóIności. Sieci odpowiada tej wiedzy metodyczne wyposażenie, zarzuceniu i wyciąganiu sieci - naukowo-przyrodnicza obserwacja. Tylko to, co pasuje do ustawionych przez siebie ram, jest dla nauki rzeczywiste.

Tymczasem rzeczywistość w dziedzinie nauki zmieniła się gruntownie od 1939 roku. Istotny przełom dokonał się przez mechanikę kwantową. Uznała ona, że precyzyjne wypowiedzi na temat rzeczywistości są niemożliwe i wszelkie zapowiedzi z góry osiągają w najlepszym razie stopień prawdopodobieństwa. Nie należy tego przypisywać tylko subiektywnej niewiedzy, lecz samemu procesowi przyrodniczemu. Swiat nie jest żadnym mechanizmem zegara. Stawanie się przyrodnicze ma charakter ciągłego rozwijania się. „Stworzenie” nie zostało zamknięte, „świat w każdym momencie staje się czymś nowym”.

Ta zmiana naukowego spojrzenia na rzeczywistość może być uważana za pełen nadziei znak łaski. Dzisiejsza wiedza przyrodnicza jest świadoma swoich granic, przejawia respekt wobec rzeczywistości. Wie ona, że świat nie znajduje się przymusowo w całkowitej zależności od człowieka. Jeśli tradycyjne przyro- 
doznawstwo pytało jedynie o pożyteczne - dla dowolnych celów - funkcje rzeczy, to dzisiaj wiadomo: rzeczy mają pewną jakość, która nie wyczerpuje się w jej wartości funkcyjnej, i pewien sens, który odsyła daleko poza funkcję. To pozwala mieć nadzieję.

\subsection{Rozwija się świadomość wzajemnej solidarności i subsydiarności pomiędzy narodami}

Swiat nasz stał się mały. Kto obserwuje go otwartymi oczyma, ten nie może nie zauważyć następujących znaków czasu: stosunki Północ - Południe i Wschód -Zachód znajdują się w trakcie poprawy na podstawie gotowości do dialogu na temat dzielących je problemów. Układ o wycofaniu rakiet średniego zasięgu (JNF) i związana z tym nadzieja na układ o wszechstronnej redukcji broni strategicznej i konwencjonalnej świadczą o wzrastającej gotowości poddania polityki bezpieczeństwa kryteriom etycznym. Ile konfliktów regionalnych dało i daje się uniknąć dzięki dialogowi Północ - Południe? Czy nie nastąpiła poprawa w losie wielu narodów właśnie przez to, że supermocarstwa poczęły rezygnować z przywłaszczonych sobie przywilejów w tzw. strefach wpływów. Tak, dlaczegóż miałbym w Polsce nie nazwać znakiem łaski tego wszystkiego, co wiąże się z pojęciami Solidarność, głasność i pieriestrojka? Przez to zostają podważone owe „struktury grzechu”, które papież Jan Paweł II w swojej encyklice Sollicitudo rei socialis tak dobitnie charakteryzuje. Z oporami, ale przecież „sprawiedliwość i pokój” zmierzają do „ucałowania się", jak mówi Psalm 85,11. Może miecze zostaną przekute na lemiesze $($ Iz 2,4$)$ ?

\subsection{Wzrasta świadomość chrześcijańskiej odpowiedzialności za świat}

Kościół także przajawia coraz więcej wyraźnych oznak ufnego spojrzenia w przyszłość. Na pewno dzisiejsze wypowiedzi brzmią o wiele powściągliwiej niż podobne soboru watykańskiego II, gdzie mniemano, że cała ludzkość jest zaangażowana przy budowie społeczeństwa prawdziwie ludzkiego. Słowo Kościoła kieruje się najpierw do mniejszych grup; ich świadomość odpowiedzialności powinna wzrastać. Istnieją wprawdzie także wśród chrześcijan niepoprawni pesymiści, którzy uważają za utopię wszelką nadzieję co do przyszłości i którzy demonizują wszelki postęp techniczny, ,ponieważ przysparza on wyłącznie trosk, nieszczęść i biedy". Niektórzy wycofali się znowu do pozaświatowej własnej intymności. Należy się jednak zapytać, czy zapał dla medytacji jest odpowiednią reakcją na wyzwania świata.

Żaden chrześcijanin nie jest wolny od rozprawy ze światem. Chrześcijanin ma prawo budować na tym, że sam Bóg przeżywa $\mathrm{z}$ nim życie ziemskie. Dla 
chrześcijanina jest prawdą niezaprzeczalną, że Boże zbawcze działanie w historii przenika zaczątkowo także ziemskie życie człowieka. Bóg skierowuje świat, także przez działanie ludzi, na innych ludzi. Chrześcijanin ma prawo działać w przekonaniu, że przyszłość ma przyszłość i że zło już w tym życiu zostało zaczątkowo pokazane przez dobro. Łaska sprawia już teraz częściowo szczęśliwe życie.

Autentycznie chrześcijańskie, praktyczne działanie (praxis) nie da się zapeszyć przez żadne czarnowidztwo. Raczej przeciwstawi ono jako alternatywy: paraliżującemu zwątpieniu - całkowite zaufanie, lękliwej małoduszności otuchę skierowaną w przyszłość, niszczącej ironii - aktywną radość. Stosowne do czasu i dotyczące losu całej ludzkości decyzje mogą być podejmowane jedynie z odwagą zmierzającą do celu i z rozumną fantazją. Stały wzrost liczby chrześcijan, włączających się w kształtowanie opinii publicznej, jest przecież znakiem łaski. Ich jasne wypowiedzi zmuszają możnych tego świata do dialogu. Tylko w ten sposób można było przyczynić się do tego, że zastopowano szaleńczą spiralę zbrojeń atomowych, przyhamowano zatruwanie środowiska, pozwolono żyć nie narodzonym, postawiono tamę dla głodu, a chorym i starym ulżono w ich biedzie, samotnym zaś przyniesiono pociechę. Nie każdy, kto swoją modlitwę łączy z odpowiedzialnym działaniem dnia codziennego, jest pelagianinem. Już Paweł wzywał do tego, żeby nie głosić charyzmatów i darów łaski, ale stosować je do budowania gminy, a także całej ludzkości. Wszystko to w sposób bardziej świadomy niż przedtem zostało w ostatnich dziesięcioleciach zintegrowane z pojęciem łaski. Przy tym stało się coraz bardziej jasne, że łaska stanowi fundament pod nadzieję, ponieważ Stwórca chciał dla swego świata także doczesnej szczęśliwej przyszłości. Świadczy o tym Biblia. Nigdzie Królestwo Boże nie jawi się jako rzeczywistość czysto pozaświatowa. Znajduje się ono raczej wszędzie tam, gdzie łaska Boża przenika już ten świat, gdzie ludzie sobie przebaczają, wzajemnie się tolerują i miłują.

Teologia na nowo pokazała, że łaskawy dla człowieka Bóg jest podstawą nadziei na życie także w tym świecie, ponieważ wiara w Boga umacnia świadomość odpowiedzialności za wszelkie życie na ziemi. Chrześcijańska świadomość odpowiedzialności rozszerza i staje się bardziej natarczywa, ponieważ wierzący ma zdać rachunek nie tylko przed sobą lub przed innymi ludźmi, lecz także przed Bogiem. Zażyłość z Bogiem ułatwia człowiekowi wierzącemu wiarę w siebie i innych ludzi, a zwłaszcza uzdalnia go do kochania każdego stworzenia.

Wreszcie Bóg jest podstawą nadziei na życie także w tym świecie dlatego, że łaska pokazuje Go jako Pana całych dziejów i w ten sposób uwalnia nas od majaków fałszywej nadziei. Łaska wiary wzmacnia świadomość, że Bóg prowadzi dzieje do rozumnego końca i przez to uzdatnia nas do znoszenia cierpliwie i zdecydowanie niedostatków i utrapień życia. Mówi nam ona, że to życie znajduje się jeszcze na drodze do ostatecznego dopełnienia. Przez powyższe 
stwierdzenie zostaje zapowiedziane przejście do eschatologicznych struktur łaski.

\section{Przewyższenie:}

\section{ESCHATOLOGICZNA „WARTOSĆ DODANA” TEGO ŻYCIA}

W dniu 13 października 1970 roku K. Rahner miał we Frankfurcie bardzo ważny wykład pod tytułem Heilsauftrag der Kirche und Humanisierung der Welt [Zbawcze zadanie Kościoła i humanizacja świata] ${ }^{8}$. W referacie tym zwraca się on przeciwko radykalnemu horyzontalizmowi, który zbawcze zadanie Kościoła usiłował utożsamić z samą tylko odpowiedzialnością za świat ${ }^{9}$. Wprawdzie doktrynalna tradycja Kościoła była zawsze świadoma, że dla pielgrzymującego człowieka na ziemi nie ma żadnego doświadczenia Boga, w którym nie byłoby pośrednictwa doświadczenia świata ${ }^{10}$. Z tego powodu Kościół ma faktycznie specjalne zadanie wobec świata, ale humanizacja nie jest wyłącznie jego sprawą. Jest to na pierwszym miejscu zadanie samego świata, wyposażonego w autonomiczne instytucje i organizacje. Byłoby osobliwym klerykalizmem, gdyby się od Kościoła żądało, ,żeby się czuł bezpośrednio odpowiedziaInym podmiotem zadań wobec świata dzisiejszej ludzkości. Kościół może i musi dzisiejszemu człowiekowi przypominać o jego odpowiedzialności za świat, ale także odsłaniać mu i uprzystępniać ostateczną głębię tej odpowiedzialności, która oznacza dla człowieka zbawienie lub zatracenie"11. W ten sposób wskazał Rahner na ów moment łaski, który potem przez J. B. Metza $\mathrm{i}$ innych został jeszcze bardziej przesunięty do centrum refleksji teologicznej o łasce: na eschatologiczny charakter obietnicy zawartej w łasce. Jeśli się łaski nie widzi wyłącznie jako ukrytej i wewnętrznej sfery zbawienia, ale jako coś, co ogarnia całą konkretną ludzką egzystencję, wówczas staje się jawnym, że znajduje się ona pod znakiem , jeszcze-nie”. Swiat, mimo najlepszego zaplanowania przyszłości, nigdy nie stanie się doskonałym, nawet jeśli to planowanie dokonuje się pod wpływem łaski lub w łasce.

$\mathrm{Z}$ wyraźnym powołaniem się na ideologię marksistowską teologowie poczęli o łasce mówić, tak euforycznie, jakby początek „nowego nieba i nowej ziemi” był już tylko „kwestią czasu”. W obawie, że nadzieja przeniesiona poza ziemię może osłabić pracę nad ziemską przyszłością, poczęli o łasce mówić tak, jak gdyby jedynym zobowiązaniem chrześcijaństwa było zamieniać ziemię w królestwo Boże, czyniąc z niej świat doskonale odkupiony.

\footnotetext{
${ }^{8}$ K. Rahner, Schriften zur Theologie, Bd. 10, Zürich-Einsiedeln-Köln 1972, s. 547 - 567.

9-10 Tamże, s. 556.

${ }^{11}$ Tamże, s. 565.
} 
Wprawdzie my także reprezentujemy tezę: to życie jest już życiem wiecznym. Podkreślamy jednak równocześnie, że ta ,identyfikacja” wprawdzie z jednej strony odsuwa przedział między tym a tamtym światem, lecz z drugiej strony życie ziemskie pojmuje jako zaczątek życia wiecznego. Chrześcijańska świadomość wiary mówi, że istnieje pewne plus, pewna „wartość dodatkowa” świata całkowicie odkupionego w stosunku do życia ziemskiego. Stwierdzenie „identyczności” między tym i wiecznym życiem nie wyklucza wspomnianej wartości dodanej. To stwierdzenie uwydatnia, że w życiu ziemskim tkwią zalążki i możliwości rozwoju, które nie są jeszcze w pełni widoczne. Jawniej dochodzi to do głosu w sformułowaniu O. H. Pescha: „Kiedy nadejdzie dopełnienie wszystkich rzeczy, wówczas objawi się ono jako dopełnienie tego, co [...] wciąż było w biegu [...]. Ale Bóg zastrzegł sobie dopełnienie i nie jest ono wynikiem ewolucji stosunków ziemskich, ani dziełem jakiegoś [...] wysiłku ludzkiego działania, nawet gdyby to było działanie z wiary"12.

Pojęcie: „eschatologiczny charakter obietnicy zawartej w łasce”, wskazuje na taką rzeczywistość, która również w antropologii humanistycznej bywa dzisiaj często określana jako otwartość człowieka na świat. Człowiek nie jest tylko zwykłym zwierzęciem. Jest on przynajmniej jakimś jak mówi Nietzsche otwartym, jeszcze nie przebadanym do końca zwierzęciem”13, „nie wyczerpanym w swoich najważniejszych możliwościach” ${ }^{14}$. „Sam przez siebie wzbudza pewne napięcie, nadzieję [...] jak gdyby z nich coś się szykowało, jak gdyby czlowiek nie był żadnym celem, a tylko drogą [...], mostem, wielką zapowiedzią"15. Jest on stworzeniem otwartym na świat, obdarzonym duchem, dzięki któremu potrafi - nawet ponad środowiskiem — poradzić sobie w świecie, który częściowo sobie wpierw stworzył i kształtował. Jego wiedza jest czymś więcej niż nagromadzeniem dat i faktów. Pod tym względem przewyższa on średniej miary komputer. Kto czlowieka traktuje jedynie zgodnie $\mathrm{z}$ jego technicznym know-how, ten go degraduje, albowiem jego ustawiczne poszukiwanie kieruje się ponad wszelkimi ograniczeniami ku temu, co nieskończone. Jego szukanie prawdy zmierza do prawdy w ogólności, a jego wola nie zadawala się nigdy tym, co zostało osiągnięte. Zmierza on ponad wszelkim konkretnie osiągniętym dobrem do dobra absolutnego. Wszelkie ramy kategorialne zostają przekroczone.

To istotowe przekraczanie samego siebie, przechodzenie granic, jest równocześnie elementem konstytutywnym uczasowienia człowieka. Innymi słowy: człowiek jest tylko wtedy naprawdę człowiekiem, kiedy swoją bytową rzeczywistość, wyrosłą z przeszłości i teraźniejszości, przerzuca w przyszłość. Jest

12 O. P. Pes sh, Freisein aus Gnade. Theologische Anthropologie, Freiburg 1983, s. 406.

${ }^{13} \mathrm{~F}$. N i t ts ch e, Jenseits von Gut und Böse, [w:] tegoż, Werke, hrsg. von K. Schlech te, Bd. 2, Munchen 1966, s. 623.

${ }_{14}$ Tamże, s. 662.

${ }^{15} \mathrm{~F}$. Ni t z s ch e, Zur Genealogie der Moral, tamże, s. 826. 
on bytem, który wciąż na nowo staje się i w żadnym momencie nie jest ostatecznie zafiksowany; jest on stawaniem się bytu [Werde-Sein].

Ta otwartość na świat czyni zrozumiałym, dlaczego człowiek może przyjąć postawę krytycznego dystansu wobec konkretnej sytuacji w tym świecie. To, co jest i co być powinno [Sein und Sollen], zostaje przez niego dostrzeżone jako dwie różne rzeczy. Swoje obecne życie widzi on jako pełne nieszczęść, swój konkretny świat jako niedoskonały i wzdycha za wszechstronniejszym spełnieniem i autentycznym szczęściem. Doświadczenie przeszłych i obecnych niedostatków pobudza go do budowania w wyobraźni projektów zmienionej przyszłości. Tutaj leży również - jeżeli się na nią patrzy z pozycji antropologicznej — podstawa ludzkiej nadziei. Tam, gdzie ktoś może zająć pozycję dystansu wobec przeszłości i teraźniejszości i nie musi koniecznie trwać w warunkach zastanych, a może tworzyć projekty lepszej przyszłości — tam znajdują się niechybnie motywy i podstawy do nadziei na lepszą sytuację. Przez to mamy jeszcze dalszy szczegół zasugerowany: kto tworzy obrazy wyrosłe z nadziei, nie może zdać się na bierny fatalizm. Wyzwalają się w nim te siły, które do tej pory drzemały. Jego projekty zmienionego świata wywołują dwojaką aktywność: najpierw walkę z tym, co negatywne, aktywny opór wobec wszystkiego, co być nie powinno, a jest; następnie budzi się w człowieku zdolność tworzenia, która umożliwia przekształcanie poznanej sytuacji obecnej na zaprojektowaną przyszłość.

Mylnie rozumie się tę nie kończącą się otwartość człowieka na świat tam, gdzie — jak u E. Blocha — czyni się z niej „zasadę nadziei”, która ustawicznie popycha do przodu, ale nie zdąża do ostatecznego celu. Jeśli rozumie się ją wyłącznie jako motor wciąż nowych poczynań humanizujących, skierowanych na ciągle otwartą przyszłość, to wtedy ową przyszłość pozbawia się treści, czyniąc z niej indyferentną otwartość. W tym punkcie zgadzają się dzisiaj liczni antropologowie.

Teologia łaski nie może pojmować otwartości człowieka na świat w sensie jakiegoś pozbawionego celu ,principium nadziei”. Dla niej istnieje eschatologiczne spełnienie i udoskonalenie, „przyszłość absolutna”, „cel ostateczny”, który udziela również odpowiedzi na pytanie, stawiane przez śmierć wszystkim „przedostatnim celom”. Jeśli się wykluczy tę absolutną przyszłość, wówczas wcześniej czy później będzie musiał się powoli zatrzymać motor, napędzający ruch pozbawiony celu, jak to już trafnie zauważył Pierre Teilhard de Chardin: „Perspektywa jakiejś totalnej śmierci (trzeba się nad tym słowem zastanowić, żeby jego destruktywną moc... zrozumieć), ta perspektywa, jeśli zostanie raz w pełni uświadomiona - potrafi wysuszyć zródła wszelkiego ludzkiego wysił$\mathrm{ku} " 16$. s. 134.

16 P. Theilhard de Chardin, Mein Glaube, [w:] tegoż, Werke, Bd. 10, Olten 1972, 
W roku 1934 Teilhard de Chardin nie wiedział jeszcze nic o śmierci atomowej i skażeniu środowiska, ale to przecież było dla niego jasne: jeśli się człowiekowi odbierze nadzieję na absolutny cel i wystawi się go na zagrożenie przez totalną śmierć, wówczas wcześniej czy później wszystkie wysiłki w budowaniu lepszego świata zostaną zaniechane. Jest gorzką, ale autentyczną prawdą naszego doświadczenia, że ludzie nie przykładają się do czegoś, o czym wiedzą, że to nie przynosi skutku (ist vergeblich). Jeśli jest to prawdą - a jest — to wtedy nie może być rzeczą obojętną, czy mamy świadomość o rzeczywistym istnieniu jakiegoś zamknięcia naszego działania, naszego ziemskiego życia, dziejów ludzkości i to zamknięcia poza wszelką śmiercią w tym świecie. Źródło naszej aktywności wyschłoby niechybnie, gdybyśmy zatracili tę świadomość. Już $\mathrm{z}$ racji logicznych wydaje mi się, że chrześcijańska odpowiedź na otwarcie się człowieka na świat jest czymś więcej niż „zwykłą projekcją” i „tanim pocieszeniem". Przekaz o ostatecznym dopełnieniu ziemskiego życia wywierał z tego właśnie powodu — od kiedy zaistniał — fascynujący wpływ na niezliczone miliony ludzi.

Chrześcijańskie orędzie łaski obiecuje wszelkiemu fragmentarycznemu urzeczywistnieniu w tym życiu ostateczne dopełnienie. Głosi ono, że łaska kiedyś całkowicie się ujawni. Jest ona już teraz w akcji, działając wyzwalająco i uszczęśliwiająco, ale dopełnienia jeszcze wciąż brakuje. To dopełnienie nie przychodzi samo z siebie, ani nie sprawia go człowiek, lecz jest ono raczej ostatecznym wkroczeniem Boga w dzieje, które On, zmieniając i udoskonalając, bierze do siebie. Przekaz ten o eschatologicznym charakterze obietnicy, tkwiącej w łasce, zawiera w sobie dwa wymiary: $z$ jednej strony jest on groźny, ponieważ pieczętuje nasze całe działanie i chcenie, wszystko osiągnięte i spełnione - nawet gdyby wymagało to wiele potu, krwi i trudu — w stanie prowizorycznym i niewykończonym. Wszystkie nasze dzieła, nawet nasza wiara, nadzieja i miłość pozostają fragmentami, które nie my, lecz tylko Bóg jest w stanie uczynić pełnymi i zbawczymi. Te słowa trafiają głęboko do serca.

Ten sam przekaz ma w sobie coś niezwykle wyzwalającego i uspokajającego. Pozbawia nas uciskającego stressu, że sami musimy wszystkiego dokonać. Uwolnieni od niego wiemy, że istnieje Ktoś, Kto nawet z naszych partackich dokonań może coś wydobyć i nasze osiągnięcia z tego świata przemienić w doskonałe szczęście. Swiadomość, że ostatecznie nie od nas samych zależy, aby całe osiągnięte przez nas powodzenie było zalążkiem, który dopiero dzięki Bożemu dopełniającemu działaniu w pełni rozbłyśnie, wprowadza nas w błogi pokój. Rzecz ważna: dane nam z łaski życie wieczne jest już w tym życiu obecne, nawet jeśli ukryte i ułamkowe, to przecież realne. Łaska jest uchwytna przez doświadczenie w tych układach, w których ludzie przeżywają swoją ziemską egzystencję. Dlatego przynależy do zadań chrześcijanina, a więc i Kościoła, wpływać tak przekształcająco na zastane sytuacje polityczne i społeczne, aby także one były przychylne ziemskiemu szczęściu ludzi. Mam tutaj na uwa- 
dze akurat wszystko to, co ze strony kościelnej dzieje się w Polsce: diakonia, caritas, zaangażowanie polityczne na rzecz demokratycznego, prawnoustrojowego społeczeństwa itd.

Trzeba jednak wciąż pamiętać: warunki bytowania nie zmienią się nigdy w ,jakiś raj na ziemi”. Cierpienie i śmierć pozostają. Cierpienia nieuniknione, jak choroby nieuleczalne, prześladowanie wiary, utratę osób bliskich, walkę z własną słabością itp. chrześcijanin przyjmuje w zespoleniu z krzyżem Jezusa Chrystusa i tłumaczy je jako oczyszczenie, które prowadzi do pogłębionej wspólnoty z Bogiem. Krzyżowa śmierć Jezusa odjęła wszystkim cierpieniom znamię oddalenia się od Boga i sprzeciwu wobec życia, a nawet samą śmierć przekształciła w możliwość ostatniego oddania się Ojcu.

Ujmując powyższe wywody krótko, wolno powiedzieć, że zdyskredytowane słowo łaska może być w całkowicie nowy sposób wyartykułowane. Rzeczywistość łaski, postawiona w kontekście ludzkiego doświadczenia, jest zdolna pokazać istotną głębię ludzkiego życia. Łaska czyni nasze życie ziemskie życiem zaczątkowo szczęśliwym. Ona udostępnia temu życiu doczesne i ostateczne dopełnienie bo „na tym polega wielkość i chwała Boga, że człowiek znajduje prawdziwe i szczęśliwe życie GLORIA DEI VIVENS" (Ireneusz, Adversus haereses, IV 20,7).

Ttumaczyt o. T. D. Łukaszuk ZP 